\title{
Pengaruh Model PBL Dengan Pendekatan Saintifik Terhadap Kemampuan CPS Ditinjau Dari Disposisi Matematis Siswa
}

\author{
(The Effect of PBL Model with Scientific Approach to CPS Ability Viewed from Student \\ Mathematical Disposition)
}

\author{
Irma Mariana ${ }^{1}$, Fahinu $^{2}$, Ruslan $^{2}$ \\ ${ }^{1}$ Alumnus Prodi Pendidikan Matematika FKIP Universitas Halu Oleo \\ ${ }^{2}$ Dosen Pendidikan Matematika FKIP dan PPs Universitas Halu Oleo; Co-author: fahinu@uho.ac.id \\ ${ }^{3}$ Dosen FMIPA dan PPs Universitas Halu Oleo
}

\begin{abstract}
Abstrak: Penelitian ini bertujuan untuk mengetahui apakah terdapat peningkatan kemampuan creative problem solving siswa dengan menerapkan model PBL dengan pendekatan Saintifik, dan untuk mengetahui apakah terdapat pengaruh penerapan model PBL dengan pendekatan Saintifik terhadap kemampuan creative problem solving siswa ditinjau dari disposisi matematis siswa. desain penelitian ini yaitu pretest-posttest control group design. Sampel dalam penelitian ini berjumlah 60 siswa dan menggunakan teknik pengambilan sampel purposive sampling. instrumen penelitian yang digunakan, yaitu tes kemampuan creative problem solving dan angket disposisi matematis siswa. hasil analisis data baik statistik deskriptif maupun inferensial menunjukkan bahwa peningkatan kemampuan CPS siswa yang diajar dengan model PBL menggunakan Pendekatan Saintifik lebih tinggi dibanding siswa yang diajar dengan model pembelajaran langsung. Berdasarkan analisis inferensial, menunjukkan bahwa adanya pengaruh PBL dengan Pendekatan Saintifik terhadap kemampuan CPS siswa ditinjau dari disposisi matematis
\end{abstract}

Kata kunci: Model PBL, CPS, Disposisi Matematis

\begin{abstract}
This study aimed to find out whether or not there was any increase in the creative problem-solving ability gained by students who applied PBL model with scientific approach, and to determine whether or not there was any increase in the creative problem-solving ability acquired by students who applied PBL model with scientific approach viewed from the students' mathematic disposition. The study used pretest-posttest control group design. Samples of the study were 60 students, which were drawn using the purposive random sampling technique. Instruments of the study comprised of a test to measure creative problem-solving ability and a questionnaire to gauge students' mathematic disposition. Result of descriptive statistics and inferential analysis showed that the increase in creative problem-solving ability gained by the students who were taught under the PBL with scientific approach was higher than that achieved by their cohorts in the direct model class. Results of inferential analysis indicated that there was an effect of PBL with scientific approach on students' creative problem-solving ability as viewed from the students' mathematic disposition.
\end{abstract}

Keywords: PBL, CPS, Mathematic Disposition

\section{PENDAHULUAN}

Peran matematika dalam dunia pendidikan secara keseluruhan sangat luas tidak hanya berkaitan tentang hal yang teknis dan ilmiah saja. Buktinya bahwa persoalan-persoalan dalam kehidupan sehari-hari dapat diuraikan dalam model matematika sehingga penyelesaiannya lebih cepat dan sederhana. Hal ini sesuai dengan tujuan pengajaran matematika di sekolah yang tertuang dalam kurikulum bahwa matematika melatih siswa untuk berpikir kritis, kreatif, inovatif, dan

mampu menyelesaikan masalah dengan tepat dan singkat serta dapat dipertanggungjawabkan.

National Council of Teacher Mathematics (2000) menetapkan bahwa terdapat 5 keterampilan proses yang perlu dimiliki siswa melalui pembelajaran matematika yang tercakup dalam standar proses, diantaranya Kemampuan Creative Problem Solving (CPS). Creative Problem Solving adalah pemecahan masalah yang melibatkan berpikir kreatif. Dimana 
kemampuan berpikir kreatif merupakan kemampuan untuk melihat bermacammacam kemungkinan penyelesaian terhadap suatu masalah. Namun kenyataanya adalah kemampuan siswa dalam pemecahan masalah kreatif masih rendah. Terlihat dari siswa hanya mampu menjawab soal sesuai dengan contoh yang diberikan guru, tidak memiliki kreativitas untuk menemukan penyelesaian lain dengan caranya sendiri atau siswa hanya dapat mengerjakan masalah matematis dengan satu cara dan cenderung mengikuti langkah-langkah yang ada dalam buku cetak. Siswa memiliki kemampuan yang rendah dalam mengerjakan soal yang memerlukan pemikiran mendalam, dan pada umumnya hanya bisa mengerjakan soal-soal yang rutin. Ini menunjukkan bahwa siswa tidak memiliki kemampuan pemecahan masalah kreatif. Sehingga, kemampuan pemecahan masalah kreatif perlu menjadi perhatian agar kemampuan tersebut dapat ditingkatkan. Dengan demikian, pemecahan masalah kreatif (Creative Problem Solving) menjadi masalah yang harus dicari solusinya.

Secara harfiah, CPS dapat diartikan sebagai kemampuan dalam merencanakan suatu cara/ide yang baru dan unik guna menjawab sebuah problem yang sedang dihadapi. Masalah yang sama seringkali diselesaikan dengan solusi yang berbeda karena situasi yang semakin dinamis. Hal ini membutuhkan kreativitas dalam menemukan solusi pemecahan masalah yang tepat. Kunci utama dari kreativitas adalah kemampuan dalam menggali ideide, metode lain, ataupun pendekatan alternatif untuk mencapai pemecahan masalah yang efektif dan efisien. Menurut Noller (1994), solusi kreatif sebagai upaya pemecahan masalah yang dilakukan melalui sikap dan pola kritis kreatif, memiliki banyak alternatif pemecahan masalah, memiliki ide baru dalam pemecahan masalah, terbuka dalam perbaikan, menumbuhkan kepercayaan diri, keberanian menyampaikan pendapat, berpikir divergen, dan fleksibel dalam upaya pemecahan masalah. Sedangkan menurut Pehnoken (1997) bahwa aktivitas pemecahan masalah dapat mengembangkan keterampilan kognitif umum yang dapat digunakan untuk mengembangkan kemampuan berpikir kreatif.

Selain kemampuan Creative Problem Solving, tujuan belajar matematika juga untuk mengembangkan perilaku positif siswa terhadap matematika dan melihat matematika sebagai sesuatu cara yang ampuh untuk menyelesaikan masalah-masalah. Perilaku positif tersebut berupa apresiasi siswa terhadap matematika yang lebih dikenal dengan sebutan Disposisi Matematis. Sebagaimana dituangkan dalam dokumen Curriculum and Evaluation Standard for School Mathematics (NCTM, 2000), disposisi tidak sekedar merujuk pada sikap tetapi juga kecenderungan berpikir dan bertindak secara positif. Penilaian disposisi matematis juga termuat dalam ranah afektif yang menjadi tujuan pendidikan matematika yaitu "siswa memiliki sikap menghargai kegunaan matematika dalam kehidupan, yaitu memiliki rasa ingin tahu, perhatian, dan minat dalam mempelajari matematika, serta sikap ulet dan percaya diri dalam pemecahan masalah (BSNP, 2006:146).

Disposisi matematis siswa berkembang ketika mereka mempelajari aspek kompetensi matematis. Sebagai contoh, ketika siswa diberi persoalan matematika yang menggunakan masalah kontekstual (real) atau relevan dengan kehidupan anak dan diawali dengan masalah yang lebih mudah, maka persoalan tersebut dapat diselesaikan dengan berbagai cara atau model-model yang sesuai dengan pengalaman anak dan kemampuan matematis yang dimilikinya. Jika anak telah mampu menyelesaikan masalah, maka anak menjadi lebih berani, percaya diri dan tidak kesulitan untuk belajar matematika. Karena merasa 
matematika tidak sulit untuk dipelajari dan berguna dalam kehidupan sehari-hari, sehingga lama-kelamaan anak menjadi senang belajar matematika. Sebagaimana Pitajeng (2006) mengatakan: Permasalahan yang diangkat dari kehidupan anak lebih mudah dipahami oleh anak, karena nyata, terjangkau oleh imajinasinya, dan dapat dibayangkan, sehingga lebih mudah baginya untuk mencari kemungkinan penyelesaian dengan menggunakan kemampuan matematis yang telah dimiliki. Sebaliknya jika masalah itu asing bagi anak, anak akan kesulitan untuk memahaminya. Jika untuk memahami masalah sudah kesulitan, maka untuk mencari penyelesaiannya akan merasa sulit.

Menyadari akan pentingnya kemampuan pemecahan masalah kreatif dan disposisi matematis siswa, maka perlu diupayakan pembelajaran dengan menggunakan pendekatan-pendekatan yang dapat memberi peluang dan mendorong seseorang untuk melatihkan kemampuan tersebut. Metode dan teknikteknik kreatif membantu siswa untuk berpikir dan mengungkapkan diri secara kreatif, yaitu mampu memberikan macammacam ide dan macam-macam jawaban dari suatu masalah dan sekaligus dapat meningkatkan kemampuan pemecahan masalah siswa. Dan dalam penelitian ini memilih Model Problem Based Learning dengan mengintegrasikan Pendekatan Saintifik.

Pembelajaran Berbasis Masalah adalah suatu strategi pembelajaran yang berpusat pada siswa, strategi ini mengolaborasikan antara pemecahan masalah dan refleksi terhadap suatu pengalaman. Suradijono (2004) mengungkapkan pendapatnya tentang Pembelajaran Berbasis Masalah, beliau menyatakan bahwa pembelajaran berbasis masalah adalah metode belajar yang menggunakan masalah sebagai langkah awal dalam mengumpulkan dan mengintegrasikan pengetahuan baru.
Forgaty (1997:3) mengemukakan pembelajaran berbasis masalah dimulai dengan masalah yang tidak terstruktur. Dari ketidakstrukturan ini siswa menggunakan kecerdasannya melalui diskusi dan penelitian untuk menentukan isu yang ada. Masalah yang disajikan dalam pembelajaran berbasis masalah merupakan masalah autentik. Masalah autentik adalah masalah yang terdapat dalam kehidupan sehari-hari dan bermanfaat langsung jika ditemukan penyelesainnya. Dengan mengangkat masalah-masalah autentik ke dalam kelas diharapkan pembelajaran akan lebih bermakna. Hal ini diperkuat dengan pernyataan John Dewey dalam Haris Mudjiman (2007:54) yang mengemukakan bahwa proses belajar akan terjadi kalau siswa dihadapkan masalah dari kehidupan nyata untuk dipecahkan, sehingga dari menghadapi masalah, siswa akan membentuk pengetahuan baru melalui langkah analisis terhadap pengetahuanpengetahuan yang mereka kumpulkan.

Pembelajaran dengan pendekatan saintifik merupakan pembelajaran yang dirancang sedemikian rupa sehingga siswa diharapkan aktif mengkonstruksi konsep melalui tahapan mengamati dalam rangka mengidentifikasi atau menemukan masalah, mengajukan pertanyaan, merumuskan dugaan, mengumpulkan data, menganalisis, menarik kesimpulan dan mengkomunikasikan konsep yang ditemukan. Dalam melaksanakan proses tersebut siswa masih perlu bantuan guru sebagai fasilitator. Dan sejalan dengan tuntutan implementasi kurikulum 2013 maka siswa akan lebih banyak berperan dalam mengkonstruksi pengetahuannya sendiri sesuai dengan karakteristik pendekatan saintifik. Dalam penelitian ini yang dimaksud dengan pendekatan saintifik adalah pembelajaran yang dirancang sedemikian rupa sehingga siswa secara aktif mengonstruk konsep, hukum, atau prinsip. Tahap-tahapan pendekatan saintifik pada penelitian ini yaitu: (1) 
mengamati;

mengumpulkan

(2) menanya;
informasi;
dan

mengasosiasikan;

mengkomunikasikan.

Model PBL dengan

mengintegrasikan pendekatan Saintifik merupakan pembelajaran dimana siswa mengerjakan permasalahan yang autentik secara ilmiah dengan maksud untuk menyusun pengetahuan mereka sendiri secara aktif dan memberi makna terhadap informasi dan peristiwa yang dialami. Kegiatan pembelajarannya meliputi mengamati, menanya, menalar, mencoba, dan menyimpulkan. Penilaian pembelajarannya dilakukan selama proses

\section{METODE PENELITIAN}

Jenis penelitian yang digunakan adalah Quasi Experiment, dengan menggunakan pretest posttest control group design. Populasi dalam penelitian ini adalah siswa kelas VII SMAN 1 Sampara. Tekhnik pemilihan sampel dilakukan dengan cara purposive sampling. Purposive sampling yaitu teknik pengambilan sampel berdasarkan pertimbangan tertentu (Sugiyono, 2011). Cara yang dilakukan dengan memilih dua kelas yang memiliki rata-rata dan varians kemampuan matematis yang relatif sama dengan melakukan uji homogenitas varians. Sehingga terpilihlah kelas VII3 sebagai kelas eksperimen dan kelas VII4 sebagai kelas kontrol yang masing-masing berjumlah 30 siswa.

Teknik pengumpulan data yang akan digunakan pada penelitian ini adalah teknik tes dan teknik angket. Teknik tes digunakan untuk mengumpulkan data yang berkaitan dengan kemampuan Creative problem Solving (CPS) siswa. Sedangkan teknik angket digunakan untuk mengumpulkan data yang berkaitan dengan disposisi matematis siswa sebelum perlakuan dengan tujuan membagi siswa ke dalam 3 kelompok yaitu siswa yang mempunyai disposisi matematis tinggi, pembelajaran. Penilaian tersebut memiliki tiga aspek utama yaitu sikap, keterampilan, dan pengetahuan.

Tujuan Penelitian ini adalah untuk mengetahui apakah terdapat Peningkatan kemampuan Creative Problem Solving (CPS) siswa setelah diajar menggunakan model PBL dengan pendekatan Saintifik, serta untuk mengetahui apakah terdapat pengaruh penerapan model PBL dengan pendekatan Saintifik terhadap peningkatan kemampuan Creative Problem Solving (CPS) ditinjau dari disposisi matematis siswa baik secara simultan maupun secara parsial.

disposisi matematis sedang, dan disposisi matematis rendah.

Tes kemampuan Creative problem Solving (CPS) ini berupa tes uraian yang diberikan pada saat pre test sebelum proses pembelajaran dan post test setelah proses pembelajaran selesai. Pre test dan post test diberikan pada kelas kontrol dan kelas eksperimen. Pre test diberikan pada awal kegiatan penelitian dan post test diberikan pada akhir kegiatan penelitian. Hasil pre test dan post test ini digunakan untuk melihat peningkatan kemampuan Creative problem Solving (CPS) siswa baik di kelas kontrol maupun di kelas eksperimen.

Disposisi Matematis siswa dalam pembelajaran Problem Basic Learning dengan pendekatan Saintifik ini diperoleh melalui skala angket, yang disusun dan dikembangkan berdasarkan 4 indikator yakni : 1) Kepercayaan diri dalam menyelesaikan masalah matematika, mengkomunikasikan ide-ide serta mampu memberi alasan yang logis, 2) Fleksibilitas dalam mengekplorasi ide-ide matematis dan mencoba berbagai metode alternatif untuk pemecahan masalah, 3) Ketertarikan, keingintahuan dan kemampuan untuk menemukan dalam pembelajaran, 4) Kecenderungan untuk 
melakukan refleksi terhadap hasil kinerjanya, yang terdiri atas 40 item pernyataan dengan 4 pilihan, yaitu Sangat Setuju (SS), Setuju (S), Tidak Setuju (TS), dan Sangat Tidak Setuju (STS). Dimana

\section{HASIL PENELITIAN}

Untuk melihat peningkatan kemampuan CPS pada penelitian ini dilakukan dengan beberapa tahap. Yakni diawali dengan memberikan angket disposisi matematis kepada siswa untuk membagi siswa dalam 3 kelompok yaitu kelompok disposisi tinggi, disposisi sedang dan disposisi rendah. Selanjutnya diberikan tes awal yaitu berupa pre-test pada materi segiempat dan segitiga dan dilanjutkan dengan penerapan model PBL dengan pendekatan Saintifik. Setelah proses pembelajaran selesai dilanjutkan dengan memberikan tes akhir berupa post test pada materi segiempat dan segitiga. Data yang diperoleh dalam penelitian ini berupa skor hasil kemampuan CPS siswa, data hasil angket disposisi matematis.

Dari hasil analisis deskriptif, dengan membandingkan pre test, post test serta $\mathrm{N}$-Gain untuk kelas kontrol dan kedua tes tersebut, baik tes kemampuan Creative problem Solving (CPS) maupun tes angket, sebelum digunakan terlebih dahulu divalidasi secara empiris.

eksperimen diperoleh bahwa keduanya mengalami peningkatan. Tetapi peningkatan yang terjadi pada kelas eksperimen lebih baik daripada kelas kontrol. Sebagai contoh perhitungan gain ternormalisasi (N-Gain) kemampuan CPS siswa kelas eksperimen atau siswa yang diajar dengan model PBL dengan pendekatan Saintifik, diperoleh rata-rata 0,34 dan standar deviasinya 0,0898. Sedangkan pada kelas kontrol atau siswa yang diajar dengan pembelajaran langsung diperoleh rata-ratanya 0,2280 dan standar deviasinya 0,0781. Hal ini berarti kemampuan CPS siswa pada kelas eksperimen lebih tinggi peningkatannya dari pada kelas kontrol. Perbandingan ratarata dan standar deviasi pre test, post test serta $N$-Gain untuk kelas kontrol dan eksperimen tersebut dapat dilihat pada gambar berikut :

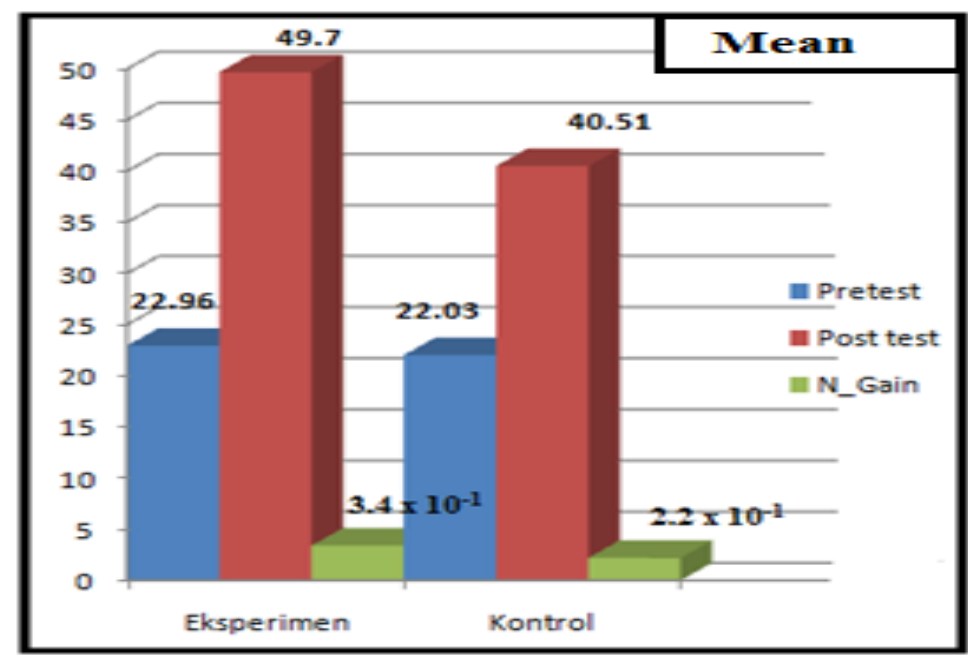

Gambar 1. Perbandingan rata-rata Pre test, Post test dan N-Gain kelas eksperimen dan Kontrol 


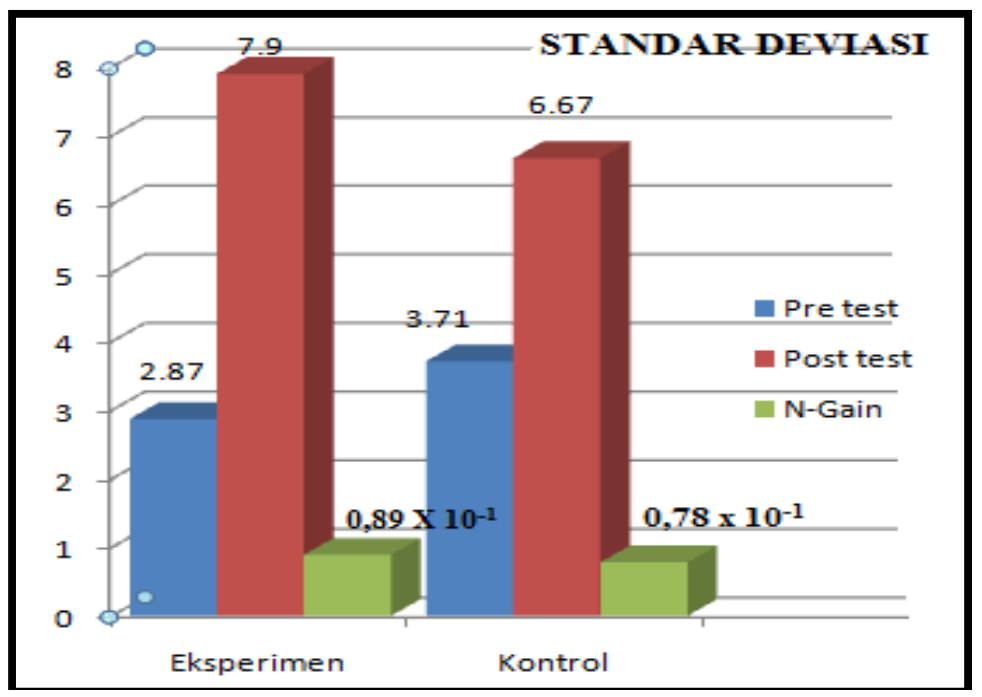

\section{Gambar 2. Perbandingan Standar Deviasi Pre test, Post test dan N-Gain kelas eksperimen dan Kontrol}

Hasil analisis deskriptif kemampuan CPS berdasarkan kategori disposisi, juga memperlihatkan adanya peningkatan pada kelas eksperimen. Hal ini terlihat dari ratarata siswa di kelas eksperimen dengan kategori disposisi tinggi mengalami peningkatan sebesar 0,44 lebih tinggi dibandingkan dengan kelas kontrol dengan kategori disposisi tinggi yaitu 0,32. Selanjutnya juga terlihat pada kategori disposisi sedang dan rendah, pada kelas eksperimen mengalami peningkatan berturut-turut sebesar 0,33 dan 0,22. Sedangkan pada kelas kontrol hanya mengalami peningkatan berturut-turut sebesar 0,29 dan 0,17.

Dari hasil uji hipotesis pertama yakni uji peningkatan kemampuan CPS baik pada kelas eksperimen maupun kontrol dengan menggunakan uji Paired Samples Test, diperoleh bahwa kelas eksperimen ataupun kelas kontrol memperoleh nilai signifikansi dibawah atau kurang dari taraf siginifikansi yang ditetapkan yakni 0,05. Hal ini berarti bahwa baik kelas eksperimen maupun kelas kontrol terdapat peningkatan kemampuan CPS yang signifikan.

Pada uji hipotesis kedua yaitu perbedaan rata-rata kemampuan CPS antara kelas eksperimen dan kontrol dengan menggunakan uji Independent T-
Test, diperoleh nilai signifikansi kurang dari taraf signifikansi yang ditetapkan yakni 0,05 . Hal ini berarti bahwa ada perbedaan yang signifikan antara kelas eksperimen atau kelas yang diajar dengan menggunakan model PBL dengan pendekatan Saintifik dengan kelas kontrol atau kelas yang diajar dengan menggunakan model pembelajaran langsung.

Selanjutnya pada uji hipotesis ketiga, yaitu perbedaan rata-rata kemampuan CPS antara kelas eksperimen dan kelas kontrol ditinjau dari disposisi matematis siswa. untuk menguji hipotesis ini digunakan uji One Way Anova dengan rancangan acak kelompok. Dari analisis ini diperoleh dua hasil yaitu memperlihatkan adanya perbedaan yang signifikan rata-rata peningkatan kemampuan Creative Problem Solving (CPS) siswa yang diajar dengan model $P B L$ dengan Pendekatan Saintifik dan model pembelajaran langsung ditinjau dari Disposisi Matematis siswa, dan hasil kedua yaitu memperlihatkan bahwa adanya pengaruh disposisi matematis terhadap kemampuan CPS siswa.

Hasil uji lanjutan diperoleh bahwa adanya hubungan yang positif antara disposisi matematis dan kemampuan CPS siswa, yang membuktikan bahwa semakin 
tinggi disposisi matematis siswa maka kemampuan CPS nya pun akan meningkat.

Uji hipotesis dengan kategori disposisi yaitu pengujian secara parsial, dilakukan dengan menggunakan uji Independent $\mathrm{T}$ Test, diperoleh bahwa untuk setiap kategori disposisi yakni baik

\section{PEMBAHASAN}

Baik secara deskriptif maupun secara inferensial menunjukkan bahwa terdapat adanya perbedaan rata-rata kemampuan CPS siswa antara kelas eksperimen yakni kelas yang diajar dengan model PBL menggunakan pendekatan Saintifik dan kelas kontrol yakni kelas yang diajar dengan model pembelajaran langsung. Dari hasil yang dikemukakan tersebut, maka dapat dikatakan bahwa terdapat pengaruh penerapan model PBL dengan pendekatan Saintifik, terhadap kemampuan CPS siswa.

Gambaran secara fisik, tentang adanya perbedaan rata-rata kemampuan CPS pada kelas yang diterapkan model PBL dengan pendekatan Saintifik, yakni dengan penilaian berdasarkan indikator penilaian CPS yang ditetapkan dalam penelitian ini, terlihat bahwa antara jawaban pre test dan post test menujukkan perbedaan yang mengarah pada peningkatan. Sebagai contoh pada indikator pertama, jawaban pre test siswa pada umunya belum menuliskan apa yang menjadi syarat perlu dan syarat cukup untuk menyelesaikan permasalahan yang diberikan. Tetapi pada jawaban post test sebagian besar siswa telah menuliskan hal tersebut dengan baik. Selanjutnya pada indikator kedua, pada jawaban pre test siswa memberikan jawaban yang kurang kreatif, tetapi pada jawaban post test siswa sudah menunjukkan kemajuan yang lebih baik. Hal serupa terjadi pula pada indikator ketiga. Dimana siswa pada jawaban pre test tidak memberikan kesimpulan dari solusi yang diperoleh, tetapi pada jawaban post test, siswa telah melakukannya dengan baik. disposisi matematis tinggi, sedang maupun rendah, terdapat perbedaan yang signifikan rata-rata peningkatan Kemampuan CPS siswa yang diajar dengan Model PBL dengan pendekatan saintifik dan siswa yang diajar dengan model pembelajaran langsung.

Peningkatan kemampuan CPS yang diperoleh dalam penelitian ini, masih dalam kategori sedang. Hal ini menunjukkan bahwa adanya faktor-faktor lain yang tidak disertakan dalam penelitian tetapi ikut serta mempengaruhi kemampuan CPS siswa. Diantaranya adalah Kesiapan siswa, Kesiapan guru dan Kebutuhan Belajar. Sebagaimana diketahui bahwa kemampuan CPS adalah kemampuan berpikir tingkat tinggi yang membutuhkan pemikiran mendalam. Hal ini bertentangan dengan kesiapan siswa yang tidak terbiasa berhadapan dengan perubahan. Siswa kurang menyukai masalah yang memberikan tantangan pada diri meraka serta kurang melibatkan diri secara langsung dalam menemukan solusi atau menyelesaikan masalah.

Kesiapan guru juga menjadi faktor yang berperan dalam peningkatan kemampuan CPS siswa. Kesiapan yang dimaksud peneliti adalah peran guru sebagai fasilitator dalam kelas yakni bagaimana mengubah cara berpikir siswa, menyiapkan siswa untuk pembaruan dan kesulitan yang akan menghadang, membantu siswa merasa memiliki masalah, dan mengkomunikasikan tujuan, hasil, dan harapan.

Faktor lain yang juga ikut andil dalam meningkatkan kemampuan CPS menurut pengamatan peneliti adalah kebutuhan belajar. Kebutuhan belajar yang dimaksudkan peneliti adalah waktu pembelajaran dan tersedianya sumber belajar. Mengenai waktu pembelajaran, dalam mengembangkan kemampuan CPS siswa membutuhkan waktu lebih panjang dari waktu yang terjadwalkan serta 
pemilihan waktu belajar dimana kondisi siswa benar-benar siap mengikuti pembelajaran. Selanjutnya tersedianya sumber belajar juga menjadi keharusan untuk menunjang tercapainya tujuan pembelajaran yakni meningkatkan

\section{KESIMPULAN DAN SARAN}

Dari hasil analisis data dan kesimpulan yang telah dikemukakan di atas, maka dapat ditarik kesimpulan sebagai berikut : terdapat peningkatan kemampuan CPS siswa baik secara deskriptif ataupun inferensial pada kelas yang menerapkan model PBL dengan pendekatan Saintifik. Terdapat pengaruh penerapan model $P B L$ dengan pendekatan Saintifik terhadap peningkatan kemampuan Creative Problem Solving (CPS), serta terdapat pengaruh penerapan model PBL dengan pendekatan Saintifik terhadap peningkatan kemampuan Creative Problem Solving (CPS) ditinjau

\section{DAFTAR PUSTAKA}

Badan Standar Nasional Pendidikan (BSNP). 2006. Standar Isi untuk Satuan Pendidikan Dasar dan Menengah. Standar Kompetensi dan Kompetensi Dasar SMA/MA. Jakarta: BSNP.

Forgaty, R. 1997. Problem Based Leraning and Multiple Intelligences Classroom. Melbourne: Hawker Brownlow Education

National Council of Teachers of Mathematics (NCTM). 2000. Principles and Standards for School Mathematics. Reston, VA: NCTM.

Noller, P. 1994. ICPS Family Functioning Scales. Journal of Adolescent. Australia : University of Queensland

Pehnoken, E. 1997. The State-of-Art in Mathematical Creativity. Dalam Zentralblatt fur Didaktik der Mathematik (ZDM)-the International Journal on kemampuan CPS. Karena semakin banyaknya sumber belajar yang dapat digunakan siswa maka semakin banyak pula referensi contoh serta pemecahan masalah yang dapat dipelajari siswa.

dari disposisi matematis siswa baik secara simultan maupun secara parsial.

Berdasarkan kesimpulan di atas dalam penelitian ini diberikan saran-saran berikut : Karena pentingnya pengembangan kemampuan CPS siswa, maka bagi para pendidik harus lebih berinovasi baik dalam hal penerapan model pembelajaran ataupun strategi yang diakukan dalam proses pembelajaran. Selain itu perlu mengubah kebiasaan yang hanya melihat keberhasilan siswa dengan patokan nilai yang ditetapkan. Serta perlu adanya pengajuan masalah matematika yang menumbuhkan kreatifitas siswa.

Mathematics Education, 97(3): 6367.

Pitajeng, 2006. Pembelajaran Matematika Yang Menyenangkan. Jakarta: Direktorat Jenderal Pendidikan Tinggi Departemen Pendidikan Nasional

Sugiyono. 2011. Statistika untuk Penelitian. Bandung : Alfabeta.

Suradijono, SHR. 2004. Problem-based learning: Apa dan bagaimana? Makalah Seminar Penumbuhan Inovasi Sistem Pembelajaran: Pendekatan Problem Based Learning berbasis ICT (Information and Communication Technology), 15/5/2004, Yogyakarta 